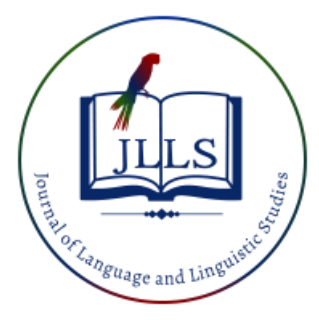

Available online at www.jlls.org

JOURNAL OF LANGUAGE

AND LINGUISTIC STUDIES

ISSN: 1305-578X

Journal of Language and Linguistic Studies, 17(3), 1457-1468; 2021

\title{
Language teaching application to English students at master's grade levels on history and macroeconomic-banking management courses in universities and colleges
}

\author{
Duong Thi Ngu a 1 iD, Do Thu Huong ${ }^{\text {b }}$ iD, Dinh Tran Ngoc Huy ${ }^{\text {c iD, Phung Thi Thanh }}{ }^{\text {d }}$ iD, \\ Esra Sipahi Döngül ${ }^{\mathrm{e}}$ í \\ ${ }^{a}$ Tan Trao Universitv. Tuven Ouang Vietnam \\ ${ }^{b}$ Dai Nam Universitv. Vietnam \\ ${ }^{c}$ Ho Chi Minh citv Vietnam - International Universitv of Japan, Japan \\ ${ }^{d}$ Tan Trao Universitv. Tuven Ouang Vietnam \\ ${ }^{e}$ Social Sciences University of Ankara, Turkey
}

\section{APA Citation:}

Ngu, D. T., Huong, D. T., Huy, D. T. N., Thanh, P. T \& Döngül, E. S. (2021). Language teaching application to English students at master's grade levels on history and macroeconomic-banking management courses in universities and colleges. Journal of Language and Linguistic Studies, 17(3), 1457-1468. Doi: 10.52462/jlls.105

Submission Date:05/05/2021

Acceptance Date:20/08/2021

\begin{abstract}
The purpose of this paper is presenting 2 examples of using English to teach history and economic subjects in universities and colleges. Another goal of this study is that we aim to enhance teaching quality in schools, colleges and universities through case teaching methods which can help students to expand discussion via open mind method. Al-Issa (2006) stated that for five decades there is an important international activity, that is English language teaching (ELT), which became a big business. And dominated by USA, it shows that English roles has been increasing on the world arena in the postcolonial/neocolonial age.
\end{abstract}

For using English to teach History subjects we have to not only catch the historical terms and topics very well but we also combine language teaching with images, ICT tools, LCDs with effective history languages.

For using English to teach economic subjects, we have to note there are key economic terms for each economic subjects as well as practice speaking and listening very often in order to deliver effective messages to students and facilitate effective communication inside classrooms. Huy, D.T.N., Hanh, N.T.T, Thao, N.T.P et al (2021) mention there is psychological and pedagogy issues when teaching at schools.

We present a typical case teaching in economic subject: analyze stock price and beta CAPM determinants in a single case study of Vietinbank - CTG in Vietnam financial market during operation period 2011-2020. Next, we will present a case teaching in Indonesian revolution for history subject. Authors also present a process of applying English in teaching history and economic via 2 specific case examples.

Keywords: English using; language teaching; economic and history; subjects; universities

\footnotetext{
${ }^{1}$ Corresponding author:

E-mail address: duongthingu@gmail.com
} 


\section{Introduction}

First, Sipahi (2019) refer to participation of people is kept at center of development in Well-being community centers. Linguistics is very important in this context.

Second, on the other hand, Tran Nguyet Minh Thu, Thuy Dung Vu Thi, Nguyen Thu Thuy, Dinh Tran Ngoc Huy (2021) said Confucianism, from China, also affect Vietnamese education.

Third, Block (2016) mentioned research or discussion framework can be supported with political economy in applied linguistics.

Fourth, Thuy Dung Vu Thi, Tran Nguyet Minh Thu, Dinh Tran Ngoc Huy, Nguyen Thu Thuy (2021) stated that there are several factors affecting education of Vietnam such as Ho Chi Minh ideologies and Western education culture.

Fifth, Dinh Tran Ngoc Huy, Pham Ngoc Van, Nguyen Thi Thu Ha (2021) also specified that language teaching, computer teaching and skills teaching are important for upgrading Vietnamese laborers during EVFTA and industry 4.0.

Because of roles of English (Peker, H. 2020). teaching in today society, then we will conduct this study to research on using English (Şentürk, B., \& Mirici, İ. H. 2019) to teach students.

\section{Research issues}

Issue 1: What are the uses of English in teaching history and economic subjects?

Issue 2: What are proposed solutions relating to English uses in teaching at colleges and universities based on analysis and discussion.

\section{Literature Review}

So we summarize previous studies as follows:

Table 1. Summary of previous studies

\begin{tabular}{|l|l|l|}
\hline Authors & Year & Contents, results \\
\hline AL-Issa & 2006 & $\begin{array}{l}\text { There are three (3) core components of ELT } \\
\text { English language teaching, cultural politics of } \\
\text { English, in case of Oman with powerful } \\
\text { ideological impact implied. } \\
\text { They include: English language (in Oman), in } \\
\text { scope of Oman education, and ELT beyond the } \\
\text { education of Oman. } \\
\text { Oman education still depend on education } \\
\text { system from North of America, Canada and UK } \\
\text { and Australia. }\end{array}$ \\
\hline Al Issa and Al riyami & 2018 & $\begin{array}{l}\text { Critical Pedagogy (CP) has been proposed as an } \\
\text { alternative pedagogy capable of meeting the } \\
\text { complex demands of teaching English within a } \\
\text { particular sociopolitical context }\end{array}$ \\
\hline Howatt and Smith & 2014 & $\begin{array}{l}\text { Over past 250 years, ELT based on periods rather } \\
\text { than methods, which tends to dominate prof. } \\
\text { thinking . }\end{array}$ \\
\hline Macaro et al & 2017 & $\begin{array}{l}\text { There is not enough evidence to confirm that } \\
\text { EMI benefits language learning and to content } \\
\text { learning. }\end{array}$ \\
\hline Lekrone and Mcquillan & $\begin{array}{l}\text { In class teaching methods we can incorporate } \\
\text { language strategies and then, involve people into }\end{array}$ \\
\hline
\end{tabular}




\begin{tabular}{|l|l|l|}
\hline & & $\begin{array}{l}\text { early teaching and } \\
\text { provide site-based coaching. }\end{array}$ \\
\hline Huy, D.T.N & 2012 & $\begin{array}{l}\text { In economic sectors such as construction, there is } \\
\text { market risk measured }\end{array}$ \\
\hline $\begin{array}{l}\text { Hang, T.T.B, Nhung, D.T.H, } \\
\text { Huy, D.T.N et al }\end{array}$ & 2020 & $\begin{array}{l}\text { Stated tourism is a good sector in economy and } \\
\text { relating to other fields }\end{array}$ \\
\hline $\begin{array}{l}\text { Dinh Tran Ngoc Huy, Nguyen } \\
\text { Thi Hang }\end{array}$ & 2021 & $\begin{array}{l}\text { Risk management mechanism need to be } \\
\text { improved at Vietnam commercial banks }\end{array}$ \\
\hline $\begin{array}{l}\text { Hac, L.D, Huy, D.T.N et al } \\
\text { Hoang Thanh Hanh, Dinh Tran } \\
\text { Ngoc Huy }\end{array}$ & 2021 & $\begin{array}{l}\text { Stated risk policies help banks to create risk } \\
\text { culture }\end{array}$ \\
\hline Dung, V.T.T et al & $\begin{array}{l}\text { Case teaching methods with English can be used } \\
\text { for accounting students }\end{array}$ \\
\hline Thu, T.N.M et al & $\begin{array}{l}\text { Mentioned western culture has affected Vietnam } \\
\text { education }\end{array}$ \\
\hline Hanh, P.T.M et al & 2021 & $\begin{array}{l}\text { Stated confucianism affect Vietnam society } \\
\text { analyze risk issues }\end{array}$ \\
\hline Pham Van Hong et al & 2021 & $\begin{array}{l}\text { Specified sustainable bank management need } \\
\text { risk management }\end{array}$ \\
\hline Huy, D.T.N, Van, P.N, Ha, N.T.T & 2021 & $\begin{array}{l}\text { Education in Vietnam need to be improved for } \\
\text { EVFTA }\end{array}$ \\
\hline Huy, D.T.N, Dat, P.M, Anh, P.T & 2020 & $\begin{array}{l}\text { Mentioned Sacombank stock price affected by } \\
\text { macro indicators }\end{array}$ \\
\hline Huy, D.T.N, Nhan, V.K et al & 2021 & 2021 \\
\hline Huy, D.T.N, An, T.T.B et al & $\begin{array}{l}\text { Bacro can affect risk in real estate industry firms } \\
\text { well }\end{array}$ \\
\hline
\end{tabular}

Beside, in economic, Hang, N.T., \& Huy, D.T.N (2021) mentioned better risk model is needed for banks to manage in macro context. Huy, D.T.N, An, T.T.B et al (2021) found out macro variables affect bank risks.

Last but not least, Hien, D.T, Huy, D.T.N, Hoa, N.T (2021) specified Ho Chi Minh ideologies has influenced much on Vietnam education and society.

And Tinh, D.T, Thuy, N.T.T, Huy, D.T.N (2021) stated teaching methodology in Vietnam schools need to be improved for new era.

\section{Methodology}

\subsection{For history teaching}

Authors mainly use combination of synthesis of data and information method, method of inductive analysis as well as explanatory methods. This study also uses historical methods.

\subsection{For economic teaching}

\section{Method and Data}

Because we believe in OLS regression with high confidence, this study use it for quantitative methods while we also use synthesis, inductive and explanatory methods.

We build a regression model with Eview software to measure impacts of factors. Vietinbank stock price is a function with 6 variables ( G-GDP growth, CPI, R - lending rate, USD/VND, IM, VNIndex, SP500, trade balance,etc.) as follows:

$\mathrm{Y}(\mathrm{CTG}$ stock price/beta CAPM $)=\mathrm{f}(\mathrm{x} 1, \mathrm{x} 2, \mathrm{x} 3, \mathrm{x} 4, \mathrm{x} 5, \mathrm{x} 6, \ldots)=\mathrm{ax} 1+\mathrm{bx} 2+\mathrm{cx} 3+\mathrm{dx} 4+\mathrm{ex} 5+\mathrm{fx} 6$ $+\ldots+\mathrm{k}$ 


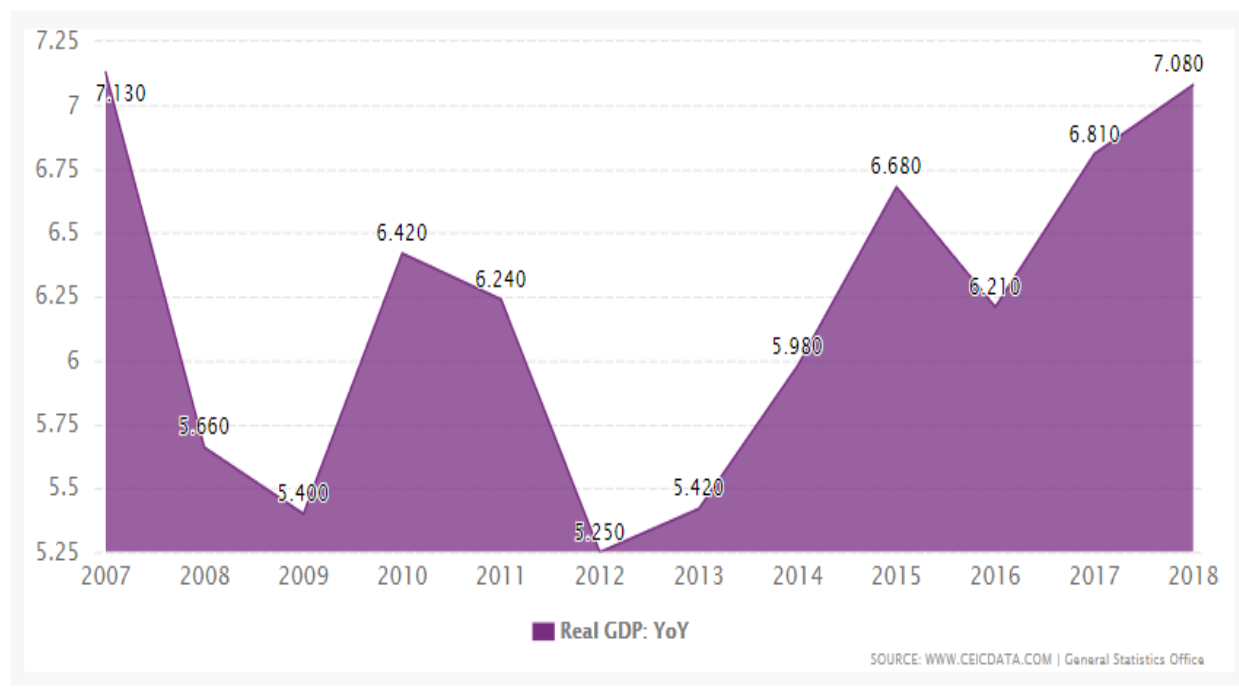

Figure 1. GDP growth rate past 10 years (2007-2018) in Vietnam

\section{Main Results}

\subsection{Example of using English for history teaching}

In this section we show a process of applying English language in teaching as:

Step 1: Introduction

\section{Introduction}

Since 17 August 1945 when Indonesia declares independence (August 17, 1945), scholars and politicians interested in the country's history have produced many valuable research works.

The study of Indonesian history is of great interest to Western scholars from both a regional and national perspective, such as: Indonesia, authored by J.D. Legge (1964); Both authors J. Bastin and J.D. Legge is less interested in the chronology of events, but only focuses on presenting expository themes about features of Indonesian history: unity in diversity, influence of Hindu culture Religion, Islam, the influence of Western colonialism on the movement to fight for and consolidate independence in Indonesia.

Indonesia has begun the transition stage from tenacious authoritarianism just after President Suharto's resignation With the events of 1998. Then the country started to change and shape laws and institutions, and experience being a citizen. Suharto's New Order is the only government that most Indonesians alive today have ever known, and its passing has sparked notable interest in reviewing and assessing earlier chapters in the national story. It is the Communists who gained a lot of specific attention.

Step 2: Note key historical terms

Indonesian revolution, PKI party, battles, struggle, fighting, Islam

Step 3: Present a case study

Indonesia revolution 1949 and the economy in later years 
On December 27, 1949, after many heroic battles that claimed the lives of more than 200,000 Indonesians, the Dutch were forced to recognize Indonesia's sovereignty. However, the nationalist leaders sold out all of Indonesia by agreeing to return all companies, farmland and mines to the Netherlands and pay an additional amount of 4.3 billion Guild (or equivalent). $\$ 10.1$ billion in 2009), that was the cost of the Dutch army during the invasion against Indonesia four years ago. This put the entire Indonesian economy under the imperial thumb and the program of complete independence was betrayed.

The Indonesian economy in the 1950s was characterized by a "chronic recession" according to Benjamin Higgins, the author of one of the most influential books of the period, Economic Development. He concluded that, "Indonesia must certainly be considered the leading failure among the least developed countries." (Benjamin H., 1969)

The above raw economic indicators for the period 1960-65 clearly show that the Indonesian economy is in a catastrophic recession. Within five years, inflation increased from $20 \%$ to $600 \%$, the budget deficit increased from $17 \%$ to $63 \%$. The immediate and direct impact of this increase in inflation was for workers and farmers, which meant a drop in their real wages, and it was not hard to spot. The money supply began to increase very rapidly from $40 \%$ in the early 1960 s to $300 \%$ in 1965 .

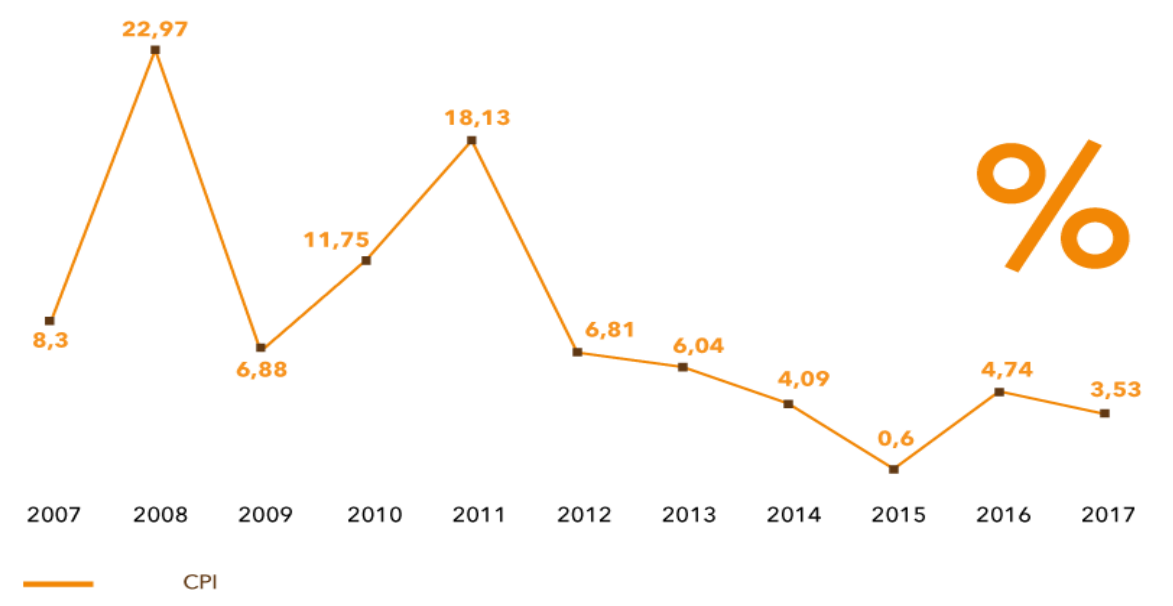

Figure 2. Inflation, CPI over past 10 years (2007-2017) in Vietnam

This increase in the money supply was directly attributable to the budget deficit, which the government managed by printing more money.

The story has been debunked by the Western capitalist powers themselves that Sukarno, like many other Third World leaders of his day, paid a disproportionate attention to political issues by economic costs; that he had politicized the country to the extreme and as a result reduced economic growth. However, this description fails to recognize the fact that political consolidation is an important step that must be taken by this newly born Republic. Allied forces have sown great chaos in the Republic, economically and politically. The imperial policy at the time was to divide Indonesia into weaker and smaller states by promoting secessionist movements throughout the archipelago.

Many rebellions, sponsored and supported by many empires, broke out and threatened national unity, which had to be dealt with not only militarily but also politically. The military effort to fight the separatists was one of the main factors that bankrupted the government. 
The Sukarno government tried to strike a balance between two main forces: the communist forces and the military forces under the reactionary generals. Behind the Communists were the working class, the poor peasants, the urban poor, and many leftist intellectuals, artists and nationalists.

\subsection{Islam with decisive role and select the way to save the country in Indonesia}

Islam entered Indonesia very early, through traders from Persia and India. The special feature of this process is that no outside force has come to force Indonesians to convert to Hinduism to Islam, and the traditional Javanese culture is still alive, not completely eclipsed. by Islamic culture. Perhaps, it was in the course of natural contact with the merchants that the natives gradually converted peacefully and voluntarily. In the process of fighting for and consolidating national independence in Indonesia (1927 - 1965), Islam played an important and decisive role in the choice of the path of national salvation according to proletarian or proletarian tendencies - capitalism in this country.

Firstly, Islam is one of the symbols of national unity, against colonialism throughout the centuries. Although this does not mean that Islam is the main basis of nationalism, when Indonesia did not have the concept of a nation, it was Islam that became the driving force behind the seeds of widespread nationalism. spread across the archipelago. SI-Sarekat Islam: The Muslim Union has become a symbol of unification between Indonesian Muslims and non-Muslims alike: "SI has successfully combined urban and rural populations, which is what No other political organization has done it before.

Even more successful was the uniting of the abangan [Mainly Muslim farmers and artisans] with the santri [Those who seek to practice the teachings of Islam in the purest], the Western methods of absorbing Western influence with the hadji [Muslims who completed the pilgrimage to Mecca], the native merchants with the working class in the cities, even the priyayi also to join SI". By using religion as a basis for unification in order to achieve significant progress among the masses of Indonesia, SI represented the masses against the colonial government and compensatory aristocracy. see, "SI reflects the grievances of the vulnerable and oppressed".

Second, the modern Islamic educational reform contributed to the struggle against the colonial rule of the Muslim intelligentsia in Indonesia. Islamic innovation began strongly when Dutch ethical policy was implemented in the early twentieth century. Reform efforts focused on the education sector to build and repair the modern Islamic education system, in order to counter the Western education system. This is also a way for Islam to combat the strong penetration of Christianity into the school and hospital system in Indonesia, mainly in Java and Sumatra. "In 1909, the first modern Islamic school was established in Padang (Minangkabau), in 1934, Minangkabau had 452 schools with 25,292 students. By 1942, Muslims in Indonesia had created an extensive network of Islamic schools from primary to university". If the SI clearly expressed political goals, Muhammadyah did not claim to pursue a political action.

"The goal of Muhammadyah as enshrined in its canon law is to spread true Islam among the people of Indonesia and improve the religious life of its members by holding public discussions about religion. ; the establishment of modern Islamic schools; publishing Islamic books and textbooks". Of course, Muhammadyah's approach to reforming Islamic teachings had a political consequence: the creation of an Islamic intellectual class, able to cope with the world's religious transitions of modern world with high national spirit.

Third, Islam contributes to preserving the indigenous culture before the invasion of Western culture. With the vast majority of the population practicing Islam, Indonesia is considered the largest Muslim country in the world. The flow of Islamic culture has gently blended into traditional Javanese culture, creating a unique blend of charm that can't be found anywhere else, as Benda puts it: "Islam in Indonesia has filtered through religious experience. Religion of India and thus acquired mystical 
elements to mount it while operating in the Indonesian environment. Therefore, the preservation of Islam itself is also the preservation of the indigenous culture, preserving traditional Javanese values before the introduction of Western culture. When the Dutch government took a series of measures to eliminate Islam from the cultural life of the indigenous population, calling Islam "the Mohammedan superstition", Javanese people remained Muslim. "Pilgrims and pilgrims continue to spread a better understanding of the spirit and nature of Islam". And although banned by the colonial government, in the eastern and southern regions of Java, Islamic customs such as: fasting, circumcising children, not eating pork, performing prayers during date... still exists.

Because Islam is a symbol of Indonesia's unity and solidarity, which classes using it as tool for uniting nation will become ruling class. The reality of the Indonesian revolution from 1927 to 1965 shows that the PKI did not consider Islam to be an active force of the nationalist movement, and even proposed the slogan:"Communism is opposed to mega-Islamism". Meanwhile, the PNI under Sukarno's leadership is trying to unite Islam with the nationalist movement, saying,"Religion in Indonesia is not like Western religion, which does not support capitalism., and Islam is not just the religion of the poor, oppressed. Therefore, it is not too difficult for the Marxists in Indonesia to come to Islam and cooperate in the common struggle against colonialism and imperialism".

Thanks to the knowledge of Islam, the path of national liberation struggle of the Indonesian bourgeoisie, represented by the bourgeois intellectuals, has widely attracted all classes of people, regardless of occupation., religion. In the end, Indonesian history has chosen the path of revolution according to the bourgeoisie and not the revolutionary path of the proletariat.As a country in the "Islamic world", but Malaysia's choice of the way to save the country is not determined by Islam. The racial factor and the new colonial rule were decisive factors for Malaysia's path to national salvation. The immigrant community of Chinese and Indians in this country is too large, even more than the native population, making national unification under the banner of struggle of the Malaysian bourgeoisie difficult. Moreover, the smart ruling policies of the British colonialists, focusing on racial divisions, made the Malaysians never hate the British to the point of having to unite closely with each other. Therefore, the goal of Malaysia's struggle for independence is only to fight the Chinese community in this country and improve the socio-economic life of the local residents.

Thus, Islam will act with decisive role in selecting the way of national salvation in Indonesia, just as Mary Somers Heidhues observed: "The most powerful element of the anti-colonial movement in Southeast Asia is religion. Religion is also a means to build trust in the face of Westernization and to unite indigenous peoples against foreign invaders". With a large and scattered geographical entity, Indonesia needs religious beliefs to unite the nation, on the other hand, religion in Indonesia is also an indispensable spiritual food in the lives of residents. since the island nation was formed until now.

\subsection{Example of using English for economic teaching}

We will present a process of applying English language as:

Step 1: Introduction of case

Vietinbank - CTG has orientation to become a bank providing services with the best quality. Therefore, the bank system will focus on growth as well as risk issues and capture market chances and revenue diversification, and strengthen handling of settled debts, risk, bad debt, effective cost management, in line with scale growth and business efficiency. The renovation of the management system is consistent with international practices and standards, improving the quality of risk management, controlling the quality of growth and improving business efficiency. 
Hence, it is necessary to evaluate impacts of multi internal and external macro economic factors on bank performance, esp. bank stock price and market risk (beta CAPM). From these analytical results, we could suggest bank and government policies to encourage and stabilize the growth of bank system and stock market in developing countries such as Vietnam.

We will then explore below issues in the case:

Issue : Measuring and evaluating effects or relationship among lots of economic factors and CTG stock price and beta?

Step 2: Note key economic terms

G: GDP growth

Rf: Risk free rate

CAPM: Capital asset pricing model

$\mathrm{R}$ : lending rate

CPI: inflation

Beta : market risk

Step 3 : Present contents of the case study

Looking at charts below, we see that:

- $\quad$ Positive correlation between $\mathrm{R}$ and beta, stock price (see chart 1)

- $\quad$ CPI and weighted beta as negative relation but positive relation b.t stock price and CPI (see chart 2)

Chart $1-\mathrm{R}$ and beta

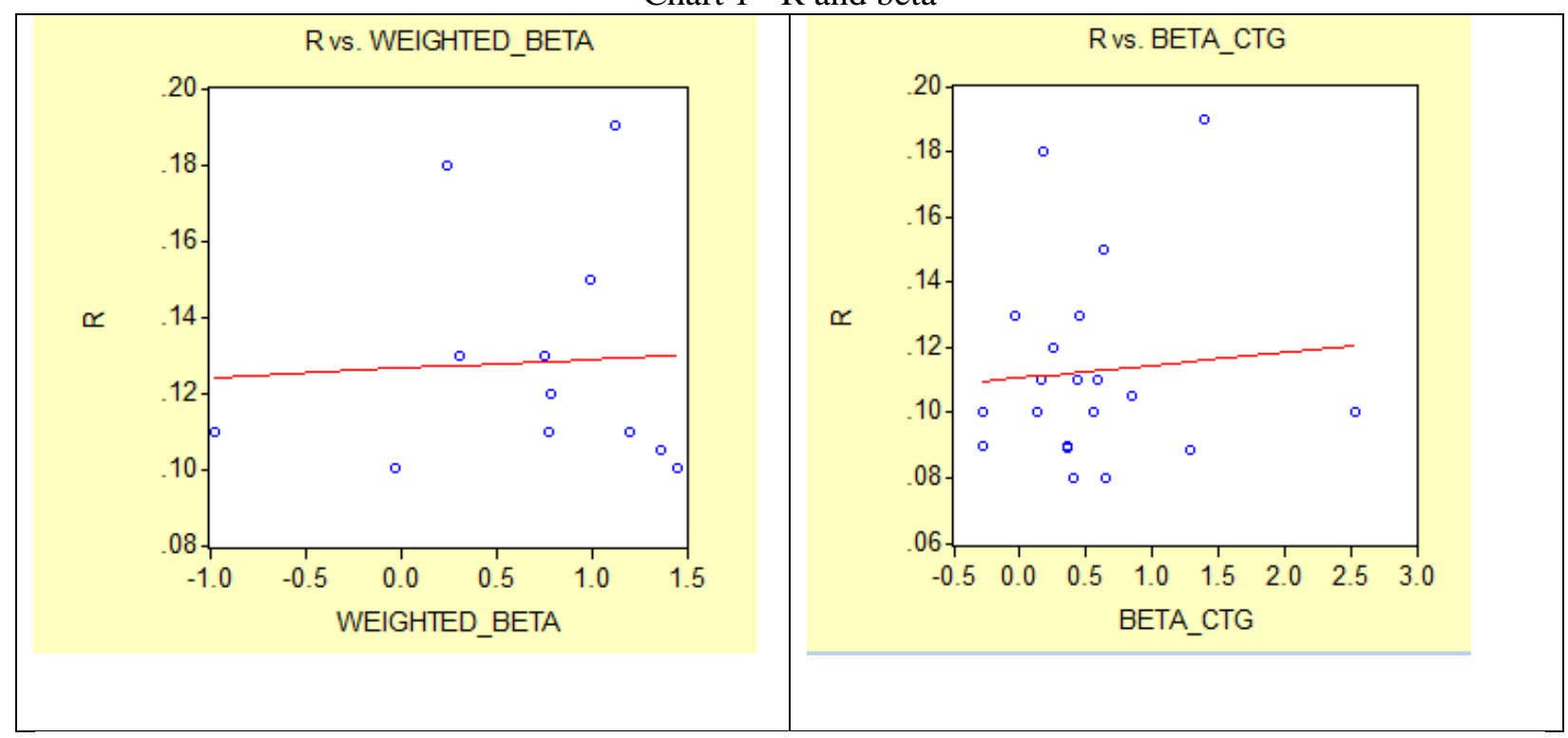

(source: author calculation and stock market) 
Chart 2 - CPI, VNIndex and weighted beta

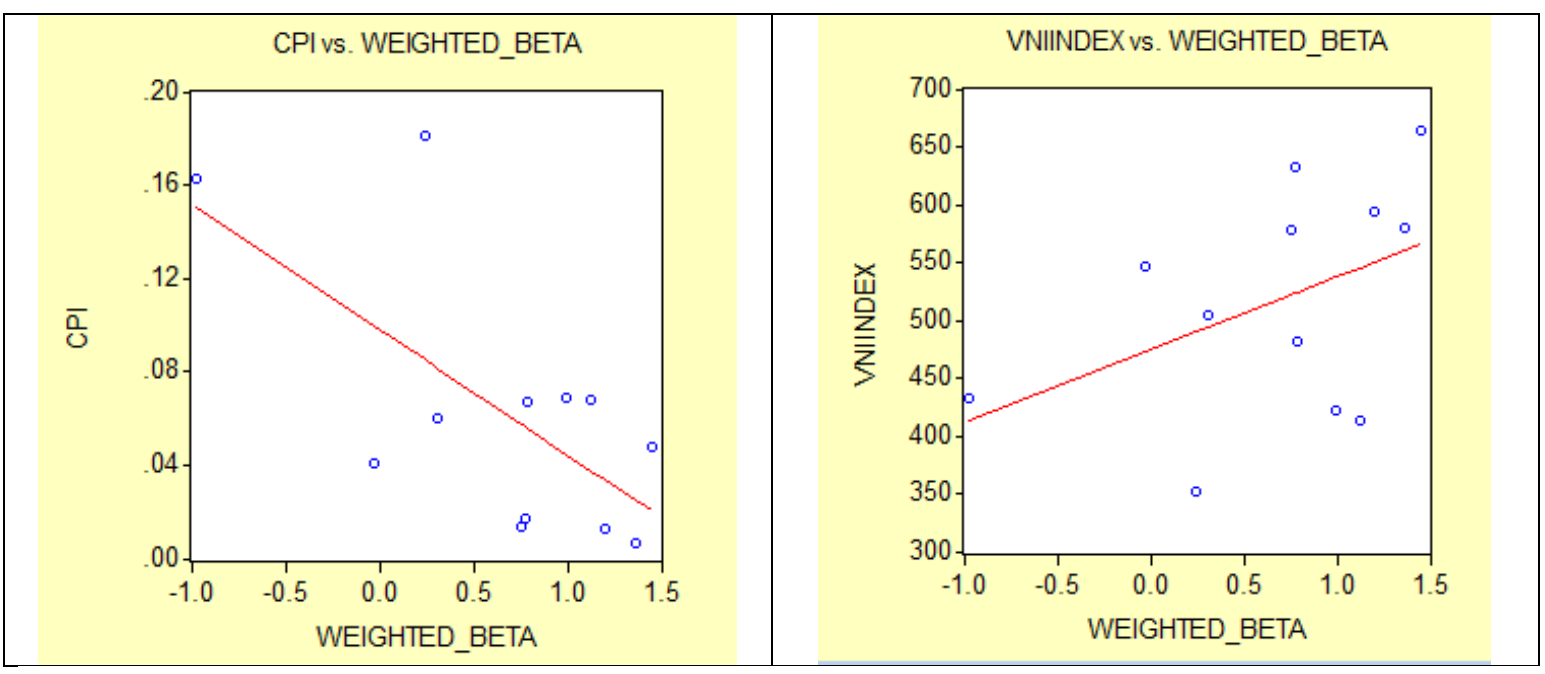

(source: author calculation and stock market)

Then we present to students the case discussion

During period 2011-2020:

From our calculated figures, CPI has negative effects on both beta CTG and weighted beta index, while IM and R have positive effects on both beta CTG and weighted beta index. We also see VNIndex has positive impact on weighted beta (chart 2).

Huy, D.T.N, Loan, B.T.T, Anh, P.T (2020) also mentioned macro factors affect stock price of Vietcombank.

\section{Discussion and Conclusion}

We go to conclusion that the use of English in teaching history and economic via case methods can be dined as a process step by step which we described above.

Because the increasing important roles of English language and their application sin teaching, we will emphasizes its global use in many developed and developing countries and in fact, it contributed very good for education and a means for human development.

Lekrone and Mcquillan (2012) stated we can take advantage of surveys, data, observations and interviews, and then we can apply Mixed methods in cycle of research in order to understand attitudes and preparedness of members or people participating to teach English learners history.

Kromydas (2017) specified for human development we need to pay attention to roles of Education which is also a good tool for economic progress moving away from its original role, so higher education need costs and lots of money.

Dat, P.M., Mau, N.D., Loan, B.T.T., Huy, D.T.N (2020) mentioned in education and other industries there is certain principles including transparency.

And Dinh Tran Ngoc Huy, Pham Ngoc Van, Nguyen Thi Thu Ha (2021) stated it is good to educate workers and students and learners before entering EFVTA. Also, Hoa, N.T, Hang, N.T, Giang, N.T.T, Huy, D.T.N et al (2021) mentioned human resources is hot issues in Vietnam for globalization. Last but not least, Duong Thi Tinh, Nguyen Thu Thuy, Dinh Tran Ngoc Huy (2021) mentioned enhancing research skills for students at schools and workplace.

Limitation of research 
We can expand our research model for other teaching subjects and other languages.

\section{Acknowledgement}

Thank you editors, friends and brothers to assist this publishing.

\section{References}

Al Issa, A.S.M., \& Al riyamy, T. (2018). Investigating TESOL Teachers' Awareness of Critical Pedagogy at Higher Education Institutions in Oman: Implications for Critical Professional Development. Khazar Journal of Humanities and Social Sciences, 21(3), DOI:10.5782/22232621.2018.21.3.35

Al-Issa, A.S.M. (2006). Ideologies Governing Teaching the Language Skills in the Omani ELT System. Journal of Language and Learning, 4(2).

Derlina, A., Bukit, N., Sahyar., \& Hassan, A., (2020). Blended Learning in English and EnglishMedium Physics Classes Using Augmented Reality, Edmodo, and Tinkercad Media. TESOL International Journal, 15(3), 111-136.

Duong Thi Tinh, Nguyen Thu Thuy, Dinh Tran Ngoc Huy. (2021). Doing Business Research and Teaching Methodology for Undergraduate, Postgraduate and Doctoral Students-Case in Various Markets Including Vietnam. Elementary education online, 20(1).

Dinh Tran Ngoc Huy, Nguyen Thi Hang. (2021). Factors that affect stock price and Beta CAPM of Vietnam Banks and Enhancing Management infomation system - Case of Asia Commercial Bank. Revista geintec Inovacao E Tecnologias, 11(2).

Dinh Tran Ngoc Huy, Pham Ngoc Van, Nguyen Thi Thu Ha. (2021). Education and computer skill enhancing for Vietnam laborers under industry 4.0 and evfta agreement. Elementary education online, 20(4).

Dinh Thi Hien, Dinh Tran Ngoc Huy, Nguyen Thi Hoa. (2021). Ho Chi Minh Viewpoints about Marxism Moral Human Resource for State Management Level in Vietnam. Psychology and education, 58(5).

Dinh Tran Ngoc Huy. (2021). Banking sustainability for economic growth and socio-economic development-case in Vietnam. Turkish Journal of computer and mathematics education, 12(2).

Hac, L.D., Huy, D.T.N., Thach, N.N., Chuyen, B.M., Nhung, P.T.H., Thang, T.D., Anh, T.T. (2021). Enhancing risk management culture for sustainable growth of Asia commercial bank -ACB in Vietnam under mixed effects of macro factors. Entrepreneurship and Sustainability Issues, 8(3).

Hang, T.T.B., Nhung, D.T.H., Hung, N.M., Huy, D.T.N., Dat, P.M. (2020). Where Beta is going-case of Viet Nam hotel, airlines and tourism company groups after the low inflation period. Entrepreneurship and Sustainability Issues, 7(3).

Hassan, A., Kazi, A. S., \& Asmara Shafqat, Z. A. The Impact of Process Writing on the Language and Attitude of Pakistani English Learners. Asian EFL Journal, 27(4.3), 260-277.

Howatt, A.P.R.., \& Smith, R. (2014). The History of Teaching English as a Foreign Language, from a British and European Perspective. Languae \& History, 57(1). https://doi.org/10.1179/1759753614Z.00000000028

Huy, D.T.N. (2015). The Critical Analysis of Limited South Asian Corporate Governance Standards After Financial Crisis. International Journal for Quality Research, 9(4), 741-764. 
Huy, D.T.N. (2012). Estimating Beta of Viet Nam listed construction companies groups during the crisis. Journal of Integration and Development, 15(1), 57-71

Huy, D. T.N., Loan, B. T.T., \& Anh, P. T. (2020). Impact of selected factors on stock price: a case study of Vietcombank in Vietnam. Entrepreneurship and Sustainability, 7(4), 2715-2730. https://doi.org/10.9770/jesi.2020.7.4(10)

Huy, D. T.N., Dat, P. M., và Anh, P. T. (2020). Building and econometric model of selected factors' impact on stock price: a case study. Journal of Security and Sustainability Issues, 9 (M), 7793. https://doi.org/10.9770/jssi.2020.9.M(7)

Huy, D.T.N., Nhan, V.K., Bich, N.T.N., Hong, N.T.P., Chung, N.T., Huy, P.Q. (2021). Impacts of Internal and External Macroeconomic Factors on Firm Stock Price in an Expansion Econometric model-A Case in Vietnam Real Estate Industry. Data Science for Financial Econometrics-Studies in Computational Intelligence, 898, Springer. http://doi-org-443.webvpn.fjmu.edu.cn/10.1007/9783-030-48853-6_14

Huy, D.T.N., An,T.T.B., Anh,T.T.K., \& Nhung, P.T.H. (2021). Banking sustainability for economic growth and socio-economic development - case in Vietnam. Turkish Journal of Computer and Mathematics Education, 12(2), 2544-2553

Kromydas, T. (2017). Rethinking higher education and its relationship with social inequalities: past knowledge, present state and future potential. Palgrave Communications, 3(1).

Legge, J.D. (1964), Indonesia, Pretice - Hall Inc., New Jersey.

Leckrone., L.S., \& MCquillan, P.J. (2012). Preparing history teachers to work with English learners through a focus on the academic language of historical analysis. Journal of English for Academic Purposes, 11 .

Macaro, E., Curle, S., Pun, J., An, J., \& Dearden , J. (2017). A systematic review of English medium instruction in higher education. Language teaching-surveys and studies, 51(1).

Nguyen Thi Hang, Dinh Tran Ngoc Huy. (2021). Better Risk Management of Banks and Sustainability-A Case Study in Vietnam. Revista geintec Inovacao E Tecnologias, 11(2).

Nguyen Thi Hoa, Nguyen Thi Hang, Nguyen Thanh Giang, Dinh Tran Ngoc Huy. (2021). Human resource for schools of politics and for international relation during globalization and EVFTA. Elementary education online, 20(4).

Sipahi, E . (2019). The role of social work in the context of international development: a cross-country analysis. $R \& S$ - Research Studies Anatolia Journal, 2(5), 136-148. DOI: 10.33723/rs.551503

Pham Van Hong, Huynh Xuan Nguyen, Dinh Tran Ngoc Huy, Le Thi Viet Nga, Nguyen Thi Ngoc Lan, Nguyen Ngoc Thach, Hoang Thanh Hanh. (2021). Sustainable bank management via evaluating impacts of internal and external macro factors on lending interest rates in Vietnam. Linguistica Antverpiensia, Issue 1, 76-87.

Phung Tran My Hanh, Nguyen Thi Hang, Dinh Tran Ngoc Huy, Le Ngoc Nuong. (2021). Enhancing Roles of Banks and the Comparison of Market Risk and Risk Policy Implications in Group of Listed Vietnam Banks During 2 Stages: Pre and Post-Low Inflation Period. Revista geintec-gestao Inovacao e Tecnologias, 11(2).

Thuy Dung Vu Thi, Tran Nguyet Minh Thu, Dinh Tran Ngoc Huy, Nguyen Thu Thuy. (2021). Effects of western culture and ho chi minh ideology on vietnam education. Elementary education online, 20(4).

Tran Nguyet Minh Thu, Thuy Dung Vu Thi, Nguyen Thu Thuy, Dinh Tran Ngoc Huy. (2021). Confucianism Theories and Its Influence on Vietnam Society. Elementary education online, 20(4). 
Peker, H. (2020). Examining the relationship between Latinos' English proficiency, educational degree, language preferences, and their perceptions on the Americans. Journal of Language and Linguistic Studies, 16(1), 290-305.

Şentürk, B., \& Mirici, İ. H. (2019). Does the ELP promote learning English as a foreign language at tertiary level?. Journal of Language and Linguistic Studies, 15(2), 695-718.

\section{AUTHOR BIODATA}

PhD Duong Thi Ngu is a lecturer holding Doctor degree, currently work at Tan Trao University, Tuyen Quang Vietnam. She has published many articles in good international and domestic journals. Her research interest are linguistic, education.

Master Do Thu Huong working as training division manager, currently manage Training office at Dai Nam University Vietnam. She has published many articles in reputable international and domestic journals. Her research interest are education and teaching quality.

MBA Dinh Tran Ngoc Huy has published more than 450 articles including more than 200 ISI/scopus articles in reputable prestigous Intl journals and domestic journals and books. His rsearch areas: business, finance, education. Visit: www.dinhtranngochuy.com .

PhD Phung Thi Thanh at present has been working at Tan Trao University, Tuyen Quang Vietnam. She has published many articles in good international and domestic journals. Her research interest are linguistic, education, teaching quality.

PhD Esra Sipahi Döngül currently work in Social Sciences University of Ankara, Turkey. She has published many good articles in well known journals. Her research interest are socialwork, business, management. 